\title{
Agronomic Comparison and In Vitro Dry Matter Digestibility of Eight Sorghums at Two Locations in Puerto Rico ${ }^{1}$
}

\author{
Salvio Torres-Cardona, Antonio Sotomayor-Rios and Fred Miller ${ }^{2}$
}

\author{
ABSTAACT
}

Eight sorghum (Sorghum bicolor L. Moench) genotypes were evaluated during four consecutive 60-day cuttings at two locations in Puerto Rico. Differences between genotypes and cuttings were significant for the eight traits studied (green forage yield, content and yield of dry matter and crude protein, in vitro dry matter digestibility, plant height and leaf area). The location $x$ genotype interaction was significant for most traits except dry matter content and in vitro dry matter digestibility (IVDMD). At both locations the best dry lorage producers over the 240-day period were ATx623 x Rio and ATx623 x TMTX430 with 34 and $30 \mathrm{t} / \mathrm{ha}$, respectively, at lsabela; and 20 and $19 \mathrm{t} / \mathrm{ha}$, respectively at Mayagüez. Average IVDMD and crude protein values of hybrids were 58 and $\mathbf{1 0 . 2 \%}$, respectively. Rio was lowest in dry forage yield but highest in IVDMD value: $62 \%$. Leaf area had a high positive correlation with the three yield criteria. A rough estimate of net profit from growing forage sorghum in Puerto Rico for milk production is $\$ 1,211 / \mathrm{ha}$.

\section{INTRODUCTION}

In Puerto Rico the most prominent perennial forage grasses have been extensively evaluated for their plant characteristics, forage yield, chemical composition and digestibility (6). On the other hand, research on the chemical composition and digestibility of forage sorghums has been more limited. According to Moyá-Guzmán (1) and Sotomayor-Ríos et al. (6), forage sorghums can have excellent value as animal feed and, in special circumstances, even be superior to the perennial forage species. In recent studies superior single cross and three-way hybrids, low in hydrocyanic acid potential and highly resistant to pests, produced more than $20 \mathrm{t}$ of dry forage/ha in 180 days (6). The demand for better forages requires continued developing and testing of new cultivars with improved nutritional value besides their high yield.

As examples of recent progress, brown midrib mutants have higher in vitro dry matter digestibility (IVDMD) when the lignin content decreases; the bloomless character has also been related positively to digestibility in feeding trials; identifying and eliminating or lowering toxic and antinutritional components also enhances forage quality (3).

${ }^{1}$ Manuscript submitted to Editorial Board January 21, 1985.

${ }^{2}$ Agronomist and Research Agronomist, respectively, United States Department of Agriculture, Science and Education, Agricultural Research Service, Southern Region, Tropical Agriculture Research Station, Mayagüez, Puerto Rico 00709; and Professor, Department of Soil \& Crop Sciences, Texas A\&M University, College Station, Texas 77843. 
Coordinated efforts of plant breeders, chemists, animal nutritionists and others promise to improve forage sorghum quality considerably.

This study was undertaken to evaluate five forage sorghum hybrids, two parental sorghums used in hybrid combination (Rio and Greenleaf) and a grain sorghum hybrid ATx623 $\times \mathrm{RT} 4330$ for green and dry forage and crude protein yields, plant height, leaf area and IVDMD at two locations in Puerto Rico.

\section{MATERIALS AND METHODS}

Experiments were conducted at the experiment farms of the Tropical Agriculture Research Station (TARS), USDA, ARS, S\&E, in Isabela and Mayagüez, Puerto Rico. The soil at the Isabela location is an Oxisol (Tropeptic Haplorthox), whereas that at Mayagüez is an Ultisol (Dystropeptic Tropudults). The planting dates at Mayagüez and Isabela were April 28 and May 9, 1983, respectively. General characteristics of the experimental sites were as follows:

\begin{tabular}{lll} 
Location & \multicolumn{1}{c}{ Isabela } & \multicolumn{1}{c}{ Mayagüez } \\
Northwestern PR & Western PR \\
Latitude & $18^{\circ} 30^{\prime} \mathrm{N}$ & $18^{\circ} 7^{\prime} \mathrm{N}$ \\
Longitude & $67^{\circ} \mathrm{W}$ & $67^{\circ} \mathrm{W}$ \\
Temperature range & $18.8-29.4^{\circ} \mathrm{C}$ & $22.2-26.1^{\circ} \mathrm{C}$ \\
Elevation & $128 \mathrm{~m}$ & $10 \mathrm{~m}$ \\
Annual rainfall & $1,675 \mathrm{~mm}$ & $2,158 \mathrm{~mm}$ \\
Soil & Oxisol (Coto) & Ultisol (Consumo) \\
Organic matter content & $2.5 \%$ & $3.2 \%$ \\
Exchange capacity & & \\
$\quad$ (meq./100 g soil) & 23 & 23 \\
pH & 5.0 & 4.8 \\
$\mathrm{P}(\mathrm{p} / \mathrm{m})$ & 53 & 3 \\
$\mathrm{~K}(\mathrm{p} / \mathrm{m})$ & 140 & 194 \\
$\mathrm{NO}_{3}(\mathrm{p} / \mathrm{m})$ & 10 & 8
\end{tabular}

The eight sorghum genotypes evaluated were: ATx623 $\times$ Rio, ATx623 $\times$ TMTx 430 , AAtlas $\times$ Rio, AT $623 \times$ Greenleaf sudangrass, ATx $378 \times$ Greenleaf sudangrass, sweet sorghum Rio, Greenleaf sudangrass and grain sorghum hybrid ATx623 $\times$ RTx 430 . The experimental design was a split-split plot arrangement in a complete block design with four replications. Main plots were genotypes, sub-plots were harvest dates and sub-sub plots were locations. Each plot consisted of 4 rows $6 \mathrm{~m}$ long and $1 \mathrm{~m}$ apart; a sampling area was $10 \mathrm{~m}^{2}$. Immediately after planting, propazine [2-chloro-4,6-bis(isopropylamino)-s-triazine] was applied at a rate of $2.5 \mathrm{~kg}$ of active ingredient/ha to control weeds. At planting, and 
after each cutting, $560 \mathrm{~kg} / \mathrm{ha}$ of $15-5-10$ fertilizer was applied to all plots. Plants were irrigated as needed to prevent moisture stress.

Four cuttings were made at 60-day intervals. Plant height (from the ground to the midpoint of the upper leaf blade) and leaf area by a portable area meter (Model LI-3000 Lambda Instruments Corporation) ${ }^{3}$ were measured before each cutting. Yields of green forage (GF), dry forage (DF), and crude protein (CP) were calculated for each cutting. Samples were analyzed for dry matter content (DMC), crude protein content (CPC) at TARS and in vitro dry matter digestibility (IVDMD) at the University of Georgia laboratories with the Tilley-Terry two-stage tech-

TABLE 1. $F$ values for the combined analyses of green and dry forage and crude protein yields; dry matter and crude protein contents; height, leaf area and in vitro dry matter digestibility of eight sorghum genotypes across four harvests at two locations in Puerto Rico

\begin{tabular}{lcccccccc}
\hline Source & $\begin{array}{c}\text { Green } \\
\text { forage } \\
\text { yield }\end{array}$ & $\begin{array}{c}\text { Dry } \\
\text { matter } \\
\text { content }\end{array}$ & $\begin{array}{c}\text { Dry } \\
\text { forage } \\
\text { yield }\end{array}$ & $\begin{array}{c}\text { Crude } \\
\text { protein } \\
\text { content }\end{array}$ & $\begin{array}{c}\text { Crude } \\
\text { protein } \\
\text { yield }\end{array}$ & Height & $\begin{array}{c}\text { Leaf } \\
\text { area }\end{array}$ & $\begin{array}{c}\text { In vilro } \\
\text { dry matter } \\
\text { digestibility }\end{array}$ \\
\hline Location (L) & $556.9^{* *}$ & 4.6 & $1031.6^{* *}$ & 0.6 & $966.0^{* *}$ & $1411.0^{* *}$ & $671.1^{* *}$ & 8.0 \\
Replication (R) & 3.3 & 0.4 & 2.5 & 1.1 & 2.6 & 0.6 & 0.8 & 1.2 \\
L $\times$ R & 2.2 & 0.9 & 1.4 & 0.1 & 1.4 & 1.0 & 0.4 & 7.0 \\
Genotype (G) & $196.0^{* *}$ & $6.1^{* *}$ & $185.3^{* *}$ & $12.7^{* *}$ & $142.9^{* *}$ & $532.4^{* *}$ & $256.7^{* *}$ & $49.7^{* *}$ \\
L $\times \mathrm{G}$ & $32.9^{* *}$ & 1.3 & $29.2^{* *}$ & $4.1^{* *}$ & $30.2^{* *}$ & $29.2^{* *}$ & $62.9^{* *}$ & 1.6 \\
L $\times \mathrm{R} \times \mathrm{G}$ & $2.1^{* *}$ & 1.3 & $2.3^{* *}$ & 1.3 & 1.3 & 1.3 & 1.5 & 1.1 \\
Cutting (C) & $474.1^{* *}$ & $14.4^{* *}$ & $487.2^{* *}$ & $80.6^{* *}$ & $297.5^{* *}$ & $90.9^{* *}$ & $66.1^{* *}$ & $38.3^{* *}$ \\
L $\times \mathrm{C}$ & $10.8^{* *}$ & 1.2 & $11.5^{* *}$ & 1.7 & $19.8^{* *}$ & $75.2^{* *}$ & $19.2^{* *}$ & $30.4^{* *}$ \\
G $\times \mathrm{C}$ & $7.3^{* *}$ & $3.8^{* *}$ & $5.5^{* *}$ & $4.2^{* *}$ & $3.8^{* *}$ & $63.4^{* *}$ & $6.5^{* *}$ & 1.0 \\
L $\times \mathrm{G} \times \mathrm{C}$ & $19.1^{* *}$ & 0.7 & $17.3^{* *}$ & 1.4 & $8.6^{* *}$ & $12.1^{* *}$ & $6.7^{* *}$ & 1.0 \\
$\overline{\mathrm{X}}$ & 34.31 & 13.78 & 4.73 & 10.6 & 0.50 & 2.44 & $4,641.46$ & 55.78 \\
C.V. (\%) & 6.9 & 2.2 & 7.0 & 7.4 & 9.9 & 3.7 & 6.5 & 5.6 \\
\hline
\end{tabular}

${ }^{1}$ Significant at the 0.01 probability level.

nique (7). Analyses of variance and regression techniques were used to interpret the data, according to Snedecor and Cochran (2).

\section{RESULTS AND DISCUSSION}

Table 1 shows $F$ values and coefficients of variation (CV) for the combined analysis of variance of the various criteria. Significant differences between locations ( $\mathrm{L}$ ) were observed for all traits except DMC, $\mathrm{CPC}$ and IVDMD. The differences among genotypes $(G)$ and cuttings (C) were significant for all traits. The significant $\mathrm{G} \times \mathrm{C}$ interactions indicate that the genotypes responded differently at different cuttings

\footnotetext{
${ }^{3}$ Trade names in this publication are used only to provide specific information. Mention of a trade name does not constitute a warranty of equipment or materials by the Agricultural Experiment Station of the University of Puerto Rico, nor is this mention a statement of preference over other equipment or materials.
} 
TABLE 2.-Mean yields of green, dry forage and crude protein; and contents of dry matter and crude protein of eight sorghum genotypes across four 60-day cuttings at two locations in Puerto Rico:

\begin{tabular}{|c|c|c|c|c|c|c|c|c|c|c|c|c|c|c|c|}
\hline \multirow{2}{*}{ Genotype } & \multicolumn{3}{|c|}{ Green forage yield } & \multicolumn{3}{|c|}{ Dry forage yield } & \multicolumn{3}{|c|}{ Dry matter content } & \multicolumn{3}{|c|}{ Crude protein yield } & \multicolumn{3}{|c|}{ Crude protein content } \\
\hline & Isabela & Mayagüez & $d^{2}$ & Isabela & Mayagüez & d & Isabela & Mayagüez & d & Isabela & Mayagüez & d & Isabela & Mayagüez & $d$ \\
\hline & & & t/ha & & & & & $\%$ & & & $t / h a$ & & & $\%$ & \\
\hline $\begin{array}{c}\text { AT } \times 623 \times \\
\text { Rio }\end{array}$ & $243.6 \mathrm{a}$ & $143.1 \mathrm{a}$ & +100.5 & $34.3 \mathrm{a}$ & $20.2 \mathrm{a}$ & +14.1 & $14.0 \mathrm{a}$ & $14.0 \mathrm{a}$ & -0.0 & $3.6 \mathrm{a}$ & $2.2 \mathrm{a}$ & +1.4 & $10.4 \mathrm{a}$ & $10.6 \mathrm{bc}$ & -2 \\
\hline $\begin{array}{l}\text { AT } 623 \times \\
\text { TMT×430 }\end{array}$ & $217.5 \mathrm{~b}$ & $137.8 \mathrm{a}$ & +79.7 & $30.1 \mathrm{~b}$ & $19.2 \mathrm{~b}$ & +10.9 & $13.8 \mathrm{~b}$ & $13.9 \mathrm{abc}$ & -0.1 & $3.1 \mathrm{~b}$ & $2.8 \mathrm{~b}$ & +1.3 & $10.4 \mathrm{a}$ & $9.3 \mathrm{~d}$ & +1.1 \\
\hline $\begin{array}{c}\text { AAtlas } \times \\
\text { Rio }\end{array}$ & $196.8 \mathrm{c}$ & $110.7 \mathrm{~b}$ & +86.1 & $26.7 \mathrm{c}$ & $15.3 \mathrm{c}$ & +11.4 & $13.6 \mathrm{~b}$ & $13.8 \mathrm{bc}$ & -0.2 & $2.8 \mathrm{c}$ & $1.5 \mathrm{c}$ & +1.3 & $10.2 \approx$ & $10.0 \mathrm{c}$ & +.2 \\
\hline $\begin{array}{l}\text { AT×623 } \times \\
\text { Greenleaf }\end{array}$ & $147.9 \mathrm{~d}$ & $104.0 \mathrm{bc}$ & +43.9 & $20.3 \mathrm{~d}$ & $14.4 \mathrm{~cd}$ & +5.9 & $13.7 \mathrm{~b}$ & I3.8 $\mathrm{abc}$ & -0.1 & $2.3 \mathrm{~d}$ & $1.7 \mathrm{~b}$ & +.6 & $11.1 \mathrm{a}$ & $11.7 \mathrm{a}$ & -.6 \\
\hline $\begin{array}{l}\text { Greenleaf } \\
\text { sudan }\end{array}$ & $141.9 \mathrm{de}$ & $96.6 \mathrm{c}$ & +45.3 & $19.4 \mathrm{de}$ & $13.1 \mathrm{e}$ & +6.3 & $13.7 \mathrm{~b}$ & $13.6 \mathrm{c}$ & +0.1 & $2.1 \mathrm{de}$ & $1.4 \mathrm{~d}$ & +.7 & $10.9 \mathrm{a}$ & $10.8 \mathrm{~b}$ & +.1 \\
\hline $\begin{array}{l}\text { ATx378 X } \\
\text { Greenleaf }\end{array}$ & $141.3 \mathrm{de}$ & $99.2 \mathrm{c}$ & +42.1 & $19.2 \mathrm{de}$ & $13.6 \mathrm{~d} e$ & +5.6 & $13.6 \mathrm{~b}$ & $13.7 b c$ & -0.1 & $2.1 \mathrm{de}$ & $1.5 \mathrm{~cd}$ & +.6 & $10.7 \mathrm{a}$ & $10.8 \mathrm{~b}$ & -.1 \\
\hline $\begin{array}{r}\text { AT } \times 623 \times \\
\operatorname{RT} \times 430\end{array}$ & $133.1 \in$ & $68.7 \mathrm{~d}$ & +64.4 & $18.2 \mathrm{e}$ & $9.6 \mathrm{f}$ & +8.5 & $13.6 \mathrm{~b}$ & $13.9 \mathrm{abc}$ & -0.3 & $2.0 \mathrm{e}$ & $1.1 \mathrm{e}$ & +.9 & $10.7 \mathrm{a}$ & $11.8 \mathrm{a}$ & -1.1 \\
\hline $\begin{array}{l}\text { Rio } \\
\bar{X}\end{array}$ & $\begin{array}{l}114.7 \mathrm{f} \\
167.1\end{array}$ & $\begin{array}{l}98.5 \mathrm{c} \\
107.3\end{array}$ & +16.2 & $\begin{array}{l}15.8 \mathrm{f} \\
23.0\end{array}$ & $\begin{array}{l}13.7 \mathrm{de} \\
14.9\end{array}$ & +2.1 & $\begin{array}{l}13.7 \mathrm{~b} \\
13.7\end{array}$ & $\begin{array}{l}13.8 \mathrm{abc} \\
13.8\end{array}$ & -0.1 & $\begin{array}{l}1.6 \mathrm{f} \\
2.5\end{array}$ & $\begin{array}{l}1.4 \mathrm{~d} \\
1.6\end{array}$ & +.2 & $\begin{array}{l}10.2 \mathrm{a} \\
10.6\end{array}$ & $\begin{array}{l}10.3 b c \\
10.7\end{array}$ & -.1 \\
\hline C.V. $(\%)$ & 5.0 & 4.4 & & 5.4 & 4.8 & & 1.3 & 1.2 & & 5.6 & 4.9 & & 4.7 & 3.5 & \\
\hline
\end{tabular}

:Means within each group followed by the same letter do not differ significantly at the 0.05 probability level.

${ }^{2}$ Mean difference by genotype between Isabela and Mayagüez. 
for all traits except IVDMD, and that genotype performance should be measured in more than one cutting. The interaction $\mathrm{L} \times \mathrm{G}$ was also significant for all traits except DMC and IVDMD.

Table 2 shows mean yields of GF, DF and CP, and DMC and CPC of the eight sorghum genotypes across four cuttings at the two locations. Hybrid ATx623 $\times$ Rio followed by ATx623 $\times$ TMTx430 produced the highest GF and DF yields at both locations. Mean DF yield of the eight genotypes was $54 \%$ higher at Isabela than at Mayagüez (23.0 vs $14.9 \mathrm{t} /$ ha); the largest difference between locations was that of ATx623 $\times$ Rio (14.1 t/ha). The DF yields of this hybrid (slightly over 34 and $20 \mathrm{t} / \mathrm{ha}$ in 240 days at Isabela and Mayagüez, respectively) compared favorably with other high-yielding forage sorghums previously studied at Isabela $(4,5)$. The CP yield of AT $623 \times$ Rio was also significantly higher than that of the remaining genotypes at both locations. Average CP yield of the eight genotypes was $67 \%$ higher at Isabela than at Mayagüez (2.5 vs $1.5 \mathrm{t} / \mathrm{ha}$ ); the largest difference observed was $1.4 \mathrm{t} / \mathrm{ha}$ for ATx $623 \times$ Rio. The CP yields of 3 and $2 \mathrm{t} / \mathrm{ha}$, produced by ATx $623 \times$ Rio at Isabela and Mayaguez, respectively, are excellent and compare favorably with topyielding tropical grasses at Isabela (4, 5). Incidence of disease, mostly rust, Puccinia purpurea Cooke; zonate leaf spot, Gleoecercospora sorghi Bain and Edgerton and, to a lesser extent, anthracnose, Colletotrichum graminicola (Cesati) Wilson, although not recorded in detail, was higher at Mayagüez than at Isabela, which could account for the difference in yield obtained. The CPC of the eight genotypes was similar at Isabela. At Mayaguiez the CPC of ATx623 $\times$ RTx430 and ATx623 $\times$ Greenleaf were significantly higher than those of the remaining genotypes.

Table 3 shows mean height, leaf area and IVDMD of the eight sorghum genotypes across four cuttings at the two locations. The first two are important anatomical factors that influence yield. In this study, at both locations, hybrids ATx623 $\times$ TMTx430 and ATx623 $\times$ Rio were significantly taller than the remaining genotypes. Average plant height of the eight genotypes was $22 \%$ greater at Isabela than at Mayagüez (268 vs $220 \mathrm{~cm}$ ); the biggest difference observed was that of AAtlas $\times$ Rio (74 $\mathrm{cm}$ ). Leaf area of AAtlas $\times$ Rio and ATx $623 \times$ Rio significantly exceeded the remaining genotypes at Isabela and Mayagüez, respectively. The average leaf area of the eight genotypes was $29 \%$ greater at Isabela than at Mayagüez $\left(5,234\right.$ vs $\left.4,049 \mathrm{~cm}^{2}\right)$; the biggest difference observed was $1,943 \mathrm{~cm}^{2}$ for ATx378 $\times$ Greenleaf. Similar results were obtained by Sotomayor-Rios et al. (6) in a previous study at Isabela.

The following tabulation shows that leaf area and plant height were positively and significantly correlated with GF, DF and CP yields and IVDMD. As in previous studies $(4,5,6)$, the association of plant height and leaf area with yield was found to be consistent; thus these two traits 
might become important selection criteria in forage sorghum improvement.

$\begin{array}{lcc} & \text { Leaf area } & \text { Plant height } \\ \text { Green forage } & 0.96^{* * 4} & 0.90^{* *} \\ \text { Dry forage } & 0.96^{* *} & 0.89^{* *} \\ \text { Crude protein } & 0.95^{* *} & 0.88^{* *} \\ \text { IVDMD } & 0.95^{* *} & 0.89^{* *}\end{array}$

Rio was the lowest dry forage yielder in this study, but showed significantly the highest IVDMD values with 61 and $63 \%$ at Isabela and Mayagüez, respectively. Most of the genotypes tested performed up to

TABLE 3.-Mean plant height, leaf area and in vitro dry matter digestibility of eight sorghum genotypes across four harvests at two locations in Puerto Rico'

\begin{tabular}{|c|c|c|c|c|c|c|c|c|c|}
\hline \multirow{2}{*}{ Genotype } & \multicolumn{3}{|c|}{$\begin{array}{l}\text { Plant } \\
\text { height }\end{array}$} & \multicolumn{3}{|c|}{$\begin{array}{l}\text { Leaf } \\
\text { area }\end{array}$} & \multicolumn{3}{|c|}{$\begin{array}{l}\text { In vitro dry matter } \\
\text { digestibility }\end{array}$} \\
\hline & Isabela & Mayagüez & $d^{2}$ & Isabela & Mayagüez & d & Isabela & Mayagüez & $\mathrm{d}$ \\
\hline & & $\mathrm{cm}$ & & & $\mathrm{cm}^{2}$ & & & $\%$ & \\
\hline AT $6223 \times$ T'M'T 430 & $326 a$ & $261 \mathrm{a}$ & +65 & $5994 \mathrm{~b}$ & $5589 \mathrm{~b}$ & +405 & $56 \mathrm{c}$ & $58 \mathrm{~b}$ & -2 \\
\hline ATx $623 \times$ Rio & $316 \mathrm{~b}$ & $261 \mathrm{a}$ & +55 & $6 \mathrm{I} 52 \mathrm{~b}$ & 5941 a & +211 & $56 \mathrm{c}$ & $60 \mathrm{~b}$ & -4 \\
\hline AAtlas $\times$ Rio & $307 c$ & $233 \mathrm{~b}$ & +74 & $6449 a$ & $4617 \mathrm{c}$ & +1832 & $55 c$ & $58 \mathrm{~b}$ & -3 \\
\hline ATx $378 \times$ Greenleaf & $264 \mathrm{~d}$ & $221 \mathrm{c}$ & +43 & $4611 \mathrm{e}$ & $2668 \mathrm{f}$ & +2943 & $48 d$ & $52 \mathrm{~d}$ & -4 \\
\hline ATx623 x Greenleaf & $258 d$ & $215 d$ & +43 & $5250 \mathrm{c}$ & $4235 \mathrm{~d}$ & +1015 & $49 d$ & $55 c$ & -6 \\
\hline Greenleaf sudan & $257 \mathrm{de}$ & $216 \mathrm{~cd}$ & +41 & $5211 \mathrm{c}$ & $2296 \mathrm{~g}$ & +2915 & $50 \mathrm{~d}$ & $53 \mathrm{~cd}$ & -3 \\
\hline $\mathrm{AT} \times 623 \times \mathrm{RT} \times 430$ & $248 \mathrm{e}$ & $195 \mathrm{e}$ & +53 & $4827 d$ & $3515 \mathrm{e}$ & +1312 & $58 b$ & $60 \mathrm{~b}$ & -2 \\
\hline Rio & $169 \mathrm{f}$ & $160 \mathrm{f}$ & +9 & $3379 \mathrm{f}$ & 3529 e & -150 & $61 \mathrm{a}$ & $63 a$ & -2 \\
\hline $\bar{x}$ & 268 & 220 & & 5234 & 4049 & & 54 & 57 & \\
\hline C.V. (\%) & 2.3 & 2.2 & & 2.7 & 5.4 & & 3.3 & 2.8 & \\
\hline
\end{tabular}

'Means within each group followed by the same letter do not differ significantly at the 0.05 probability level.

${ }^{2}$ Mean difference by genotype between Isabela and Mayagüez.

expectations, verifying earlier reports $(5,6)$ on their potential for forage production in the tropics. Excellent DF yields, high protein content and IVDMD values were obtained 60 days after planting. At least four 60 day interval harvests with excellent yield, CPC and IVDMD values were shown to be possible. These results also confirmed a previous finding (6) that ATx623 is a male-sterile line with potential for use in the development of superior $F_{1}$ forage sorghum hybrids in Puerto Rico.

\section{ECONOMIC CONSIDERA'TIONS}

Previous studies in Puerto Rico have shown that the cost/ha for harvesting, chopping and transporting 40 tons of dry forage is $\$ 2,263$ or

\footnotetext{
${ }^{4}$ Significantly different from zero at $\mathrm{P}=0.01$.
} 
$\$ 56.6 / \mathrm{t}$ (6). If a $20 \%$ wastage of chopped forage is assumed, total yields/ ha yearly of forage sorghum consumed would be about 32 tons. As shown in this study, the best hybrids are capable of producing over $8 \mathrm{t} /$ ha every 60 days. Vicente-Chandler et al. (8) have shown that well-managed grass pasture can provide all the feed required by a $550 \mathrm{~kg}$ cow producing 10 liters of milk daily. Although it has not yet been determined what level of milk production can be obtained from green chopped forage sorghum, a theoretical yield of $8 \mathrm{~kg}$ of milk daily will be assumed. Corresponding TDN requirements would be $4.35 \mathrm{~kg}$ for maintenance plus $2.9 \mathrm{~kg}$ for milk production $(8 \times .36)$, a total of $7.25 \mathrm{~kg}$ daily. Under these conditions, each $\mathrm{kg}$ of milk requires $0.9 \mathrm{~kg}$ of TDN. As a rough estimate, it can be assumed that 32 tons of dry forage/ha with $50 \%$ TDN content could provide the necessary nutrients to produce $17,778 \mathrm{~kg}$ of milk/ha. In Puerto Rico this would have a market value of approximately $\$ 8,000$ $(\$ .45 / \mathrm{kg})$. Assuming that forage accounts for one third of the cost of producing milk, total production costs can be estimated at $\$ 6,789$; thus the net profit from growing forage sorghum for milk production would be $\$ 1,211 /$ ha yearly $(\$ 8,000-\$ 6,789)$.

\section{CONCLUSIONS}

Significant differences between locations were observed for all traits except DMC, CPC and IVDMD. The interaction $\mathrm{L} \times \mathrm{G}$ was significant for all traits except DMC and IVDMD. The DF and CP yields were higher at Isabela than at Mayagüez, but IVDMD was similar. The topyielding hybrids in terms of DF were ATx623 x Rio and ATx623 $\times$ TMTx430. Sweet sorghum Rio was the lowest dry forage producer but showed the highest significant IVDMD values at both locations. A rough estimate of net profit from growing forage sorghum in Puerto Rico for milk production is $\$ 1,211,00 /$ ha.

\section{RESUMEN}

Cinco hibridos de sorgo forrajero, dos progenitores y un hibrido de sorgo de grano se evaluaron en términos de forraje verde (GF), materia seca (DM), proteína bruta (CP), altura de planta, área foliar y digestibilidad aparente in vitro (IVDMD) durante 240 días en dos localidades en Puerto Rico. Se llevaron a cabo cuatro cortes, el primero a los 60 días y los siguientes cada 60 días aproximadamente. Al combinarse los datos de los cuatro cortes, se notaron diferencias significativas entre localidades en todos los caracteres, excepto DMC, CPC y IVDMD. La interacción localidad $\times$ genotipo fue significativa en todos los caracteres excepto DMC y IVDMD. Las diferencias entre genotipos y cortes fueron significativas en todos los caracteres. En general, las producciones más altas de DF y CP se observaron en Isabela. En ambas localidades los mejores productores de DF y CP fueron los híbridos ATx623 $\times$ Rio y ATx623 × TMTx430. La 


\section{JOURNAL OF AGRICULTURE OF UNIVERSITY OF PUERTO RICO}

variedad de sorgo azucarado Rio, aunque registró la menor producción de DF y CP, obtuvo los valores más altos de IVDMD. Los resultados indican, que los híbridos que registraron los rendimientos más altos tienen magníficas potencialidades para usarse como forrajeros en Puerto Rico. La producción de DF del híbrido ATx623 $\times$ Rio de $34.3 \mathrm{Tm} / \mathrm{ha}$ en un periodo de 240 dias o de $14 \mathrm{Tm} / \mathrm{ha} /$ día con una CP de $10 \%$ es excelente, especialmente cuando la yerba se puede cortar en los trópicos a intervalos cortos. Si se supone una producción de forraje seco de aproximadamente $40 \mathrm{Tm} / \mathrm{ha} / a n ̃ o$, es posible producir leche a base de sorgo forrajero con una ganancia neta de $\$ 1,211 /$ ha/año.

\section{LITERATURE CITED}

1. Moyá Guzmán, J. R., 1982. Rendimiento, consumo voluntario, composición quimica y digestibilidad de tres variedades de sorgo forrajero (Sorghum bicolor L. Moench). MS Thesis, Univ. P.R., Mayagüez Campus.

2. Snedecor, G. W, and W. C. Cochran, 1967. Statistical Methods. The lowa State Univ. Press. 6th ed, Ia., USA. pp. 39-84.

3. Sotomayor-Ríos, A. and L. Telek, 1983. Breeding sorghum for forage quality. In Proc. 'Plant breeding in sorghum workshop', Mexico City, April 10-16.

4. - - , and S. Torres-Cardona, 1984. Agronomic Performance, hydrocyanic acid potential (HCN-p) and heterosis in forage sorghum hybrids, J. Agtic. Univ. P.R. 68 (2): 13141.

5. - - , and - - 1984. Agronomic comparison, heterosis and hydrocyanic acid potential (HCN-p) of sudangrass-sorghum and sudangrass-sudangrass hybrids and their parents, J. Agric. Univ. P.R. 68 (2): 143-55.

6. - - , - - a and A. Quiles-Belén, Sorghum responses to $\mathrm{N}$ fertilization and harvest intervals. J. Agric. Univ. P.R. (submitted for publication).

7. Tilley, J. M. A. and R. A. Terry, 1963. A two stage technique for the in vitro digestion of forage crops, J. Br. Grassl. Soc. 18: 104-11.

8. Vicente Chandler, J., R. Caro Costas, F. Abruña y S. Silva. 1983. Producción y utilización intensiva de las forrajeras en Puerto Rico. Esta. Exp. Agric. Univ. P.R. Bol. 271. 